\title{
ENTREPRENEURSHIP EDUCATION IN THE HIGHER EDUCATION SYSTEM IN REPUBLIC OF NORTH MACEDONIA
}

\author{
Katerina Shapkova Kocevska ${ }^{1}$
}

Received: June 20, 2019 / Revised: July 31, 2019/ Accepted: October 15, 2019

(C) Association of Economists and Managers of the Balkans, 2019

\begin{abstract}
This paper examines the entrepreneurship education programs present at the universities in Republic of North Macedonia. The analysis covers the overall higher education system, including both state and private universities. The authors use qualitative content analysis in order to explore and compare different aspects of the programs, including: objectives and expected outputs of the entrepreneurial program, its content, learning and grading methods, quality assurance and literature list. The findings of this work are expected to raise awareness about the importance of entrepreneurship education in the country and to serve as evidence for the relevant stakeholders to deliver more competitive, innovative and business supporting educational system.
\end{abstract}

Keywords: Entrepreneurship; Business friendly environment; Entrepreneurial education; Higher education; Content analysis.

\section{JEL Classification A23 $\cdot$ I21 $\cdot$ L26}

This paper was presented at the Fifth International Scientific Conference on Knowledge Based Sustainable Development - ERAZ 2019 - May 23, Budapest, Hungary, www.eraz.org.rs

Katerina Shapkova Kocevska

k.shapkova@pf.ukim.edu.mk

1 Faculty of Law Iustinianus Primus, University Ss. Cyril and Methodius, blvd. Goce Delchev 9b, 1000 Skopje, N. Macedonia 


\section{INTRODUCTION}

One of the most important policies of the European Union (EU) is Enterprise policy. Its aim is to create business friendly environment by strengthening competitiveness, facilitating structural change and stimulating small and medium-sized enterprises (SMEs). Ultimately, this is a joint and organized effort in order to stimulate innovations and job creation.

In the 2018 Report on the Former Yugoslav Republic of Macedonia (European Commission, 2018) is noted that the country is moderately prepared in the area of Enterprises and industrial policy. Moreover, the country has not made any progress in the reporting period. Key priorities of the country should be to adopt a new industrial policy and strategies for SMEs; (2) introduce initiatives to increase the skills in companies, notably SMEs, to adopt new methods and technologies; and (3) develop measures to link foreign direct investment with local companies.

However, creating business-friendly environment is closely related to creating business-friendly formal and non-formal institutions. Educational system, understood as a system for organized dissemination of knowledge and skills, is one of the crucial institutions for fulfilling this task. Higher education is expected to provide students with valuable specialized knowledge and skills and to stimulate innovative thinking, risk taking and competitiveness. In this paper, we emphasize the importance of entrepreneurial education in delivering these results.

Entrepreneurship is relatively new and modern concept. Although, there are many definitions on what entrepreneurship is, and what it is not, there is no universal definition about what this concept represents. However, there is a general consent that entrepreneurship is related to innovations, creativity, leadership, that ultimately lead to progress. Entrepreneurship is more than just starting and running up a business. Entrepreneurship creates perspectives for individuals to seek opportunities, take risks and develop new ideas. The contributions entrepreneurs and entrepreneurial firms provide to the economy are immense and include stimulating innovations, promoting technical change, increasing productivity and decreasing unemployment. Entrepreneurship plays the crucial and indispensable role of providing the "social glue" that binds together both high-tech and "Main Street" activities (Small Business Administration [SBA], 1998).

Entrepreneurship has appeared in the late XX century, but has quickly evolved into powerful economic factor stimulating economic growth and innovations. The raise of the entrepreneurship kindled expansion of entrepreneurship education, as well, especially at university level. Consequently, rapid development of entrepreneurship courses and programs has emerged.

This paper examines the entrepreneurship education in the higher education (hereinafter: HE) institutions at the universities in North Macedonia. The analysis covers the overall education system, including both state and private universities. We use qualitative content analysis in order to explore and compare different aspects of the programs, including: objectives and expected outputs of the entrepreneurship course, its content, learning and grading methods, quality assurance and reading list.

The findings of our work are expected to raise awareness about the importance of entrepreneurship education in the country and to serve as evidence for the relevant policy -makers to deliver more competitive, innovative and business supportive educational system. 


\section{LITERATURE REVIEW}

It is becoming clear that entrepreneurship can be taught. Business educators and professionals have evolved beyond the myth that entrepreneurs are born, not made (Kuratko, 2005). As one of the pioneers of entrepreneurship education explains it, entrepreneurship is not magic nor mystery, it is a discipline and can be learned (Drucker, 1985). Moreover, “... most of the empirical studies surveyed indicated that entrepreneurship can be taught, or at least encouraged, by entrepreneurship education" (Gorman, Hanlon, \& King, 1997, p. 63). According Plaschka and Welsch (1990), the question of whether entrepreneurship can be taught is obsolete, because it is widely accepted that entrepreneurs are the key to innovation, productivity and competition. As a result, entrepreneurship education is moving towards integrative, comprehensive, and holistic programs.

One of the first studies analyzing entrepreneurship education was published in 1988 (Hills, 1988). Here, the author concludes that the university entrepreneurship education is in the embryonic stage and although the number of university offerings is increasing, many faculty and administrators regard this field with doubt.

Beginning of entrepreneurship education dates back to 1947, when Myles Mace held the first entrepreneurship course in the United States at the MBA department of Harvard's Business School (Katz, 2003). However, the rise of the entrepreneurship courses at university level begun in 1970s. Data show that in 1970 there were 16 universities and colleges offering entrepreneurship courses, compared to over 400 schools offering entrepreneurship courses in 1995. Vesper and Gartner (1997) identified several possible reasons that led to increased number of schools that offered entrepreneurship courses in 1970 s, such as number of corporations per capita stopped falling around 1969 and began to rise, new magazines celebrating entrepreneurship began to emerge, negative connotations of the term "entrepreneur" began to shift, certain industry sectors, such as electronics, had cultivated a population of individuals who could create new products etc.

The rise of entrepreneurship education has been a global trend. In 1990s certain schools began to offer more than one course in entrepreneurship and started developing entrepreneurship programs (Vesper and Gartner, 1997). In 2003, entrepreneurship education in U.S. has expanded to more than 2,200 courses at over 1,600 schools; 277 endowed positions; 44 refereed academic journals, mainstream management journals devoting more issues (some special issues) to entrepreneurship; and over 100 centers (Kuratko, 2005; Katz, 2003). The number of search results at Amazon.com website containing phrases "small business" and "entrepreneurship" in 1998 was 2,723 active titles, while in 2019 is over 50,000 titles. Also, as of May 2001, there were 44 entrepreneurship journals accepting papers, with a new one starting approximately every 4 months (Katz, 2003, p. 292).

The focus of entrepreneurship education is set on the "process of providing individuals with the ability to recognize commercial opportunities and the insight, self-esteem, knowledge and skills to act on them. It includes instruction in opportunity recognition, commercializing a concept, marshalling resources in the face of risk, and initiating a business venture" (Jones and English, 2004, p. 416). Similarly, Kourilsky (1995) understands entrepreneurship education as opportunity recognition, marshalling of resources in the presence of risk, and building a business venture. Other scholars (Bechard and Toulouse, 1998) assess entrepreneurship education as a compilation of formalized teachings with purpose to inform, train, and educate individuals interested in business creation, or small business development. Alternatively, this concept can be defined in terms of creativity and innovation applied to social, governmental, and business arenas (Gottleib and Ross, 1997). 
Compared to business management, entrepreneurship should be defined more broadly because it includes creativity, risk taking, and innovation (Brown, 2000). Moreover, "entrepreneurial education emphasizes imagination, creativity, and risk taking in business whereas traditional business schools tend to over-emphasize quantitative and corporate techniques at the expense of more creative skills" (Porter, 1994).

There is a diversity of academic views and positions on what compose entrepreneurship as a field of study and as a program. Furthermore, there is an open debate among scholars about the content of the entrepreneurship programs (Vesper and Gartner, 1997). From one point of view, "entrepreneurship education can also be considered as a process of development of skills of the individuals to develop business plans. It focuses on the expertise that is used to conceive of and commercialize a business opportunity" (Jones and English, 2004, p.416). Roach (1999) suggested the following topics to be considered at an entrepreneurship course at university level: knowledge of the characteristics of an entrepreneur; understanding ability to recognize business opportunities; development of skills and knowledge to create feasibility plans for a business venture; ability to evaluate different business strategies; and develop skills and means regarding collection of market information for project evaluation. Most important features of an entrepreneurship course were development of a business plan project, and the role of an entrepreneur as a speaker and a role models, analysis of case studies, lectures and assigned readings (Hill, 1998).

Relevant literature identifies three separate sources of entrepreneurial understanding and knowledge (Kuratko, 2005). The first source incorporates publications from research projects and popular publications, such as academic journals, textbooks and books on entrepreneurship, (auto)biographies of entrepreneurs, compendiums about entrepreneurs, periodicals, newsletters, conference proceedings, government publications and reports etc. Second source is data collected by direct observation of entrepreneurs' behavior by using different tops, such as interviews, surveys, case studies etc. And the third source of entrepreneurial understanding covers oral presentations by practicing entrepreneurs, such as speeches and presentations.

Also, the growing literature on entrepreneurship education tends to argue that a different learning environment is required to support the study of entrepreneurship within a university setting (Gibb, 2002). The content of the entrepreneurship courses can also determine the teaching method. On one hand, innovative entrepreneurship education should be instructed by experimental learning, analysis of case studies, development of problem-solving skills, creativity, product design etc. On the other hand, because entrepreneurship education often covers business disciplines, such as finance, marketing and management, teacher-centered and ex-cathedra lectures are characteristic for the course curriculums.

Vesper and Gartner (1997) conducted a mail survey in 1994, sent to deans at 941 business schools in United States, Canada and other countries. Based on the results of the survey, these authors formulated seven criteria for ranking entrepreneurship programs, including courses offered, faculty publications, impact on community, alumni exploits, innovations, alumni start-ups, and outreach to scholars. The content of the most frequently offered entrepreneurship courses at both the undergraduate and graduate levels consisted entrepreneurship or starting new firms, small business management, field projects/venture consulting, starting and running a firm, venture plan writing, and venture finance.

Effects of entrepreneurship education in HE will change the nature and improve the quality of business starts of graduates in the long run. Entrepreneurship education is likely to be a signifi- 
cant contributor to graduates start-ups, and societal and intellectual attitudes towards entrepreneurship in the long run (Galloway and Brown, 2002). The study suggests that aspirations on the part of the students of entrepreneurship towards business ownership are ambitious, relative to responses from graduate alumni and that there was much concentration in the business service sector by those who owned or were in process of starting a business.

Also, one recent study aims to identify the relationship between entrepreneurship education, prior entrepreneurial exposure, perceived desirability and feasibility, and entrepreneurial intentions for university students, by using Ajzen's theory of planned behavior and Shapero's entrepreneurial event model (Zhang, Duysters and Cloodt, 2013). The authors came to conclusion that there is a significant negative impact on entrepreneurial intentions from exposure to entrepreneurial activity and a significant positive impact from entrepreneurship education. Other variables, such as, gender, university type, and study major also have significant effects on the relationship between entrepreneurship intentions and entrepreneurship education.

However, entrepreneurship education might face some challenges due to the arbitrability in concept definition and understanding. Pittaway and Cope (2007), by using Systematic Literature Review (SLR) methodology, came to conclusion that although there are significant funds flowing into entrepreneurship education, there are concerns about what entrepreneurship education actually is and what outputs are expected to be created by investing in this type of education. The authors appeal for further research in entrepreneurship education, in order to develop objective criteria for impact evaluation of the public policies promoting this concept.

At the end of this section, we can conclude that entrepreneurship education is very important concept that will certainly evolve, develop and grow as an academic discipline in future. The remarkable growth of this area has marked the end of the $20^{\text {th }}$ and the beginning of the $21^{\text {st }}$ century. One future uncertainty is the form or forms of entrepreneurship education that dominate in the new century (Katz, 2003, p. 298).

\section{ENTREPRENEURSHIP EDUCATION IN NORTH MACEDONIA}

The aim of this paper is to explore the entrepreneurship education at HE institutions in Republic of North Macedonia. The higher education system, or the tertiary education in the country, is organized by both public and private organizations. Public tertiary education includes higher vocational schools, faculties and religious schools, while private tertiary education is offered by private vocational schools and faculties. Total number of tertiary education institutions in the country in the academic 2017/2018 year was 135 institutions, of which 74 schools were public (55 percent) and 60 private (45 percent). Huge majority of the higher education institutions are faculties (97 percent) and rest of the institutions are higher vocational schools and religious schools (3 percent).

Another important aspect with regard to the higher education infrastructure in the country is student enrollment. In the academic 2017/2018 year, there were total 56,941 students, by whom $85.7 \%$ were enrolled in public tertiary education, and $13.9 \%$ in private tertiary education in the country (State Statistical Office, 2019, p.12). The number of students has diminished by 2\% in 2017/2018 year, compared to the previous academic year. Female students outnumber male students. The number of female students enrolled in academic $2017 / 2018$ is 31,669 (55.6\% of total). Total 15,094 students $(26.5 \%$ of total) are enrolled in first year undergraduate studies. 
Data about presence of entrepreneurship education in the curriculums of the undergraduate and graduate programs of the tertiary education institutions in the country were collected through analysis of course syllabuses attached at the web sites of the HE institutions. Data collection process was organized from $10^{\text {th }}$ to $20^{\text {th }}$ March 2019. In the research process, academic programs of all $135 \mathrm{HE}$ institutions were analyzed. The results about integration of entrepreneurship education in curriculums of the institutions are presented in Table 2.

Table 1. Structure of tertiary education in North Macedonia in academic 2017/2018 Source: State statistical office, 2018.

\section{Tertiary institutions}

Public tertiary institutions

Higher vocational schools

Faculties

Religious faculties

\section{Private tertiary institutions}

Higher vocational schools

Faculties

\section{Number of institutions}

Table 2. Entrepreneurship education at HE institutions in North Macedonia, 2018 Source: Author's calculations.

\begin{tabular}{|l|c|c|c|c|c|}
\hline Status of HE institution & Yes & $\begin{array}{c}\text { Yes, but } \\
\text { syllabus is } \\
\text { not available }\end{array}$ & No & $\begin{array}{c}\text { No information } \\
\text { available }\end{array}$ & Total \\
\hline Public higher vocational schools & & & 1 & & 1 \\
\hline Public faculties & 9 & 29 & 26 & 8 & 72 \\
\hline Religious schools & & & 2 & & 2 \\
\hline Public higher vocational schools & & 1 & & & 1 \\
\hline Private faculties & 5 & 12 & 42 & & 59 \\
\hline Total & 14 & 42 & 71 & 8 & 135 \\
\hline
\end{tabular}

Only 14 out of 135 HE institutions (10\% of total) offer entrepreneurship education in their programs and have published the course syllabus at the web page of the institution. Considerable number of HE institutions (42 HE institutions or 31\% of total) offer entrepreneurship course, but the curriculum is not available at the institutions' official web site. However, more than a half of HE institutions in the country do not offer entrepreneurship education (53\% of total). We can conclude that entrepreneurial education is not fully integrated in the academic curriculum of $\mathrm{HE}$ institutions in the country.

Furthermore, we noticed that there was a difference between academic programs of public and private HE institutions with regard to entrepreneurship education. Generally, greater proportion of public HE institutions offer entrepreneurship course compared to the private HE institutions. Thus, approximately half of the public HE institutions offer some form of entrepreneurship education to their students. On the other hand, only $29 \%$ of the private HE institutions have included entrepreneurship education in their curriculums. 
Also, it was interesting to examine inclusion of entrepreneurship education in different academic fields. Educational process in HE in the country covers standard academic fields organized in the following categories: Biotechnical sciences (11 programs), Medical sciences (7 programs), Natural sciences and mathematics (7 programs), Technical and technological sciences (44 programs), Social sciences (67 programs), Humanities (25 programs) and Religious sciences (2 programs). Total number of different academic programs offered by the HE institutions in the country is 163 . Total number of HE institutions differs from the number of academic programs, due to the fact that some of the faculties and schools in the country offer programs in more than one field. For example, Faculty for agriculture from University Goce Delchev - Shtip offers programs in 3 fields (Biotechnical sciences, Social sciences, Technical and technological sciences), or Faculty of Natural Sciences and Mathematics from University Ss Cyril and Methodius - Skopje offer programs in Biotechnical sciences, Social sciences and Natural sciences and mathematics.

Table 3 summarizes the results about integration of entrepreneurship education in HE institutions' curriculums presented by academic field. We can conclude that entrepreneurship education is more frequently included in HE institutions that offer programs in the field of social sciences and technical and technological sciences. This should not be a surprise, having in mind the specifics of each academic field and nature and purpose of entrepreneurship education. However, although entrepreneurship education is quite popular in the abovementioned two fields, still there is room for stimulation of HE institutions working in other fields to develop entrepreneurship education and courses.

Table 3. Entrepreneurship education, by field, 2018

Source: Authors' calculations.

\begin{tabular}{|l|c|c|c|c|c|}
\hline Academic field / program & Yes & $\begin{array}{c}\text { Yes, but } \\
\text { syllabus is } \\
\text { not available }\end{array}$ & No & $\begin{array}{c}\text { No information } \\
\text { available }\end{array}$ & Total \\
\hline Biotechnical sciences & $/$ & 5 & 6 & $/$ & 11 \\
\hline Religious sciences & $/$ & $/$ & 2 & $/$ & 2 \\
\hline Medical sciences & $/$ & $/$ & 7 & $/$ & 7 \\
\hline Social sciences & 7 & 21 & 37 & 2 & 67 \\
\hline $\begin{array}{l}\text { Natural sciences and } \\
\text { mathematics }\end{array}$ & 2 & 1 & 1 & 3 & 7 \\
\hline $\begin{array}{l}\text { Technical and technological } \\
\text { sciences }\end{array}$ & 4 & 21 & 18 & 1 & 44 \\
\hline Humanities & 1 & 5 & 17 & 2 & 25 \\
\hline Total & 14 & 53 & 88 & 8 & 163 \\
\hline
\end{tabular}

\section{CONTENT ANALYSIS}

Qualitative content analysis covered the syllabuses that were available at the web sites of the HE institutions in the country. Total 14 entrepreneurship education course syllabuses were analyzed, 9 from public HE institutions, and 5 from private institutions. The tertiary education institutions that offer entrepreneurship course(s), but the course syllabuses are not published at HE institution's web site were omitted from the analysis.

The content analysis covered several aspects of the entrepreneurial education, including: course title, academic calendar, reading list, course goals, content of the course and methods. 


\subsection{Course title}

The analysis of syllabuses showed that entrepreneurship education in HE is present in a form of undergraduate or graduate courses. In $50 \%$ of the analyzed cases, the course is titled solely "Entrepreneurship", while in $43 \%$ of the cases the title of the course is "Entrepreneurship and small business". Only in 7\% of the cases the course is titled differently (e.g. Social entrepreneurship). The title of the course might be correlated with the goals and content of the program, and with entrepreneurial intentions of the students, as well. We can conclude that entrepreneurship education in North Macedonia is understood in a traditional sense, only covering broad topics, such as entrepreneurship or small business management.

\subsection{Academic calendar}

Content analysis of the course syllabuses showed that entrepreneurship education in majority of cases $(71 \%$ of total) is an elective course. Only in one case, that is the case of the private Faculty of entrepreneurial business at the University for Tourism and management in Skopje, there is an obligatory course titled "Entrepreneurship and small business" offered at undergraduate level. The rest of the available syllabuses do not contain information about the status of the course (obligatory or elective).

Besides status of the course, we were interested in the weight of the course measured in ECTS 2 credits. ECTS credits express the volume of learning based on the defined learning outcomes and their associated workload (ECTS Users' Guide, 2015, p.10). According this system, 60 ECTS credits are allocated in one full-time academic year. Our analysis has showed that the number of credits for entrepreneurship courses at the universities vary from 3 to 8 EKTS credits. The average number of ECTS credits is 5.4 per course, while the median number of credits is 5 ECTS credits per course.

\section{3. $\quad$ Reading list}

Regarding analysis of literature list of the entrepreneurship courses, two aspects were taken into consideration. First, we were interested in origin of authors, more specifically if the instructors teaching entrepreneurship courses use literature written by domestic authors or materials that are written by respected international authors. Second, since entrepreneurship discipline is dynamic and rapidly growing, we were examining if the literature follows this trend by analyzing the year of publication of the text books and other materials used for the entrepreneurship courses.

For the purposes of the first research question, we developed a coding system with the following alternatives: 1) all sources included in reading list are written by domestic authors, 2) all sources included in reading list are written by foreign authors, 3) sources in reading list are written by both domestic and foreign authors, and 4) the course syllabus does not contain information about the authors of the reading materials. The analysis of the available syllabuses showed that in 10 cases ( $71 \%$ of total) the reading list is consisted of materials written by both domestic and foreign authors. Usually, domestic literature, in a form of a textbook or a reader, is written by the course instructor. International textbook that is most often used is "Entrepreneurship: Starting and Operating A Small Business" by Steve Mariotti and Caroline Glackin, translated into Macedonian language. Only in 2 cases (14\% of total) reading list for the entrepreneurship course is consisted from work of domestic authors.

$2 \quad$ Abbreviation for: European Credit Transfer and Accumulation System. 
Second aspect, with regard to the literature for the course (reading list), is the year of publication. Since majority of courses use more than one source in the reading list, we were analyzing separately the year of publication of the first, second and third source given in the reading list. We selected three periods: most recent (2015 - today), recent (2010-2014) and remote (before 2010). The results of the analysis are given in Table 4.

Table 4. Year of publication of the sources in the reading list on entrepreneurship courses Source: Author's calculation.

\begin{tabular}{|l|c|c|c|}
\hline \multirow{2}{*}{ Reading list } & \multicolumn{3}{|c|}{ Year of publication } \\
\cline { 2 - 4 } & 2015- today & 2010-2014 & Before 2010 \\
\hline First source & 3 & 7 & 2 \\
\hline Second source & 0 & 7 & 4 \\
\hline Third source & 0 & 4 & 3 \\
\hline
\end{tabular}

In the case of the first source, only 3 courses use literature published later then 2015 . In the majority of courses (7 cases) instructors use literature that is published between 2010-2014. We recorded two courses where the first source is material published before 2010 as a primary source for the entrepreneurship course. Years of publication for the second and the third source that are used in the entrepreneurship education in HE institutions date back to 2010 or before.

\subsection{Course content}

As it was discussed earlier, there is not a consensus on how university level entrepreneurship course should be tailored and what topics should it cover. Content analysis of the entrepreneurship courses at HE institutions in the country showed that most popular topics covered in course syllabus are 1) introduction to entrepreneurship and 2) running a business (7 cases). Next, five courses cover topics such as marketing and legal aspects, followed by management (including human resources management) and finance topics. Some of the courses include lectures on communication skills and computer skills, but those are exception (each topic is covered only in one case).

\subsection{Methodology}

Course content is narrowly related to the teaching methodology used in the course by the teacher / instructor. The analysis showed that most of the entrepreneurship courses use rather traditional methodology, such as teacher - centered lectures ( 7 cases, or $50 \%$ of total observations). Other techniques that are used are presentations from guest lecturers ( 2 cases), analysis of case studies ( 2 cases), student projects ( 3 cases) and other (3 cases). These results should not be a surprise, since entrepreneurship courses in HE institutions in the country cover conventional topics, such as management of small business, marketing and finance.

\section{CONCLUSION}

Entrepreneurship is fast growing global phenomena, which brings multiple benefits to the economies and societies worldwide. Entrepreneurship is closely related to innovations, technological progress and economic prosperity. Entrepreneurship education is a powerful tool for teaching entrepreneurship and encouraging entrepreneurial intentions.

Entrepreneurship education at HE institutions in North Macedonia is in its early beginnings. Although entrepreneurship courses are present in the curriculums of many HE institutions in the 
country, still there is noteworthy number of schools that do not offer some form of entrepreneurship education to their students. Another occurrence that was detected is that HE institutions are relatively inert and do not publish information about course syllabuses at the official web pages of the institutions.

With regard to the content of the courses, entrepreneurship is broadly defined and covers traditional business matter. Our recommendation to HE institutions is to modernize the entrepreneurship courses by upgrading and updating the course subject, to include topics such as digital skills or innovation policy in the course agenda, to renew the reading list with up-to-date and relevant literature and to develop other teaching methods beside teacher - centered lectures.

\section{REFERENCES}

Bechard, J.P., \& Toulouse, J.M. (1998). Validation of a didactic model for the analysis of training objectives in entrepreneurship. Journal of Business Venturing, 13(4), 317-32.

Brown, C. (2000). Entrepreneurial Education Teaching Guide, 00-7, Vol. 00-7, CELCEE Kaufman Centre for Entrepreneurial Leadership Clearinghouse on Entrepreneurship Education.

Drucker, P.F. (1985). Innovation and entrepreneurship. New York: Harper \& Row.

European Commission (2015). ECTS Users' Guide. Available at: https://ec.europa.eu/education/ ects/users-guide/docs/ects-users-guide_en.pdf [Accessed 1 June 2019]

European Commission. (2018). The former Yügoslav Republic of Macedonia 2018 Report. Available at: https://ec.europa.eu/neighbourhood-enlargement/sites/near/files/20180417-the-former-yugoslav-republic-of-macedonia-report.pdf [Accessed 19 April 2019]

Galloway, L., \& Brown, W. (2002). Entrepreneurship education at university: a driver in the creation of high growth firms? Education + Training, 44(8/9), 398-405. doi:10.1108/00400910210449231

Gibb, A. (2002). In pursuit of a new 'enterprise' and 'entrepreneurship' paradigm for learning: creative destruction, new values, new ways of doing things and new combinations of knowledge. International Journal of Management Reviews, 4(3), 33-69.

Gorman, G., Hanlon, D., \& King, W. (1997). Some research perspectives on entrepreneurship education, enterprise education, and education for small business management: A ten-year literature review. International Small Business Journal, 15, 56-77.

Gottleib, E., \& Ross, J.A. (1997). Made not born: HBS courses and entrepreneurial management. Harvard Business School Bulletin, 73, February, 41-5.

Hills, G. E. (1988). Variations in University entrepreneurship education: An empirical study of an evolving field. Journal of Business Venturing, 3(2), 109-122.

Jones, C., \& English, J. (2004). A contemporary approach to entrepreneurship education. Education + Training, 46(8/9), 416-423. doi:10.1108/00400910410569533

Katz, J. A. (2003). The chronology and intellectual trajectory of American entrepreneurship education. Journal of Business Venturing, 18(2), 283-300. doi:10.1016/s0883-9026(02)00098-8

Kourilsky, M.L. (1995). Entrepreneurship Education: Opportunity in Search of Curriculum. Kansas City, MO.: Center for Entrepreneurial Leadership, Ewing Marion Kauffman Foundation.

Kuratko, D. F. (2005). The Emergence of Entrepreneurship Education: Development, Trends, and Challenges. Entrepreneurship Theory and Practice, 29(5), 577-598. doi:10.1111/j.15406520.2005.00099.x

Pittaway, L., \& Cope, J. (2007). Entrepreneurship Education: A Systematic Review of the Evidence. International Small Business Journal, 25(5), 479-510. 
Plaschka, G.R., \& Welsch, H.P. (1990). Emerging structures in entrepreneurship education: Curricula designs and strategies. Entrepreneurship Theory and Practice, 14(3), 55-71.

Porter, L. (1994). The relation of entrepreneurship education to business education. Simulation and Gaming, 25(3), 416-9.

Roach, K. (1999), Entrepreneurial Education Planning for Success Syllabus. Clarkesville, GA.: North Georgia Technical Institute.

Small Business Administration. (1998). The new American revolution: The role and impact of small firms. Washington, DC: Small Business Administration, Office of Economic Research.

State Statistical Office (2018). Enrolled students in undergraduate studies, 2017/2018. Available at: http://www.stat.gov.mk/Publikacii/2.4.18.11.pdf [Accessed 15 June 2019]

Vesper, K. H., \& Gartner, W. B. (1997). Measuring progress in entrepreneurship education. Journal of Business Venturing, 12(5), 403-421. doi:10.1016/s0883-9026(97)00009-8

Zhang, Y., Duysters, G., \& Cloodt, M. (2013). The role of entrepreneurship education as a predictor of university students' entrepreneurial intention. International Entrepreneurship and Management Journal, 10(3), 623-641. doi:10.1007/s11365-012-0246-z 